Volume: 1 | Number 1 | pp. 1 - 3

ISSN: 2633-352X (Print) | ISSN: 2633-3538 (Online) journals.tplondon.com/ijor

First Received: 6 November 2020

TRANSNATIONAL PRESS ${ }^{\circledR}$

DOI: https://doi.org/10.33182/ijor.v1i1.1221

\title{
Editorial:
}

\section{Launching the International Journal of Religion}

Jeffrey Haynes ${ }^{1}$, Ahmet Erdi Ozturk ${ }^{2}$, Eric M. Trinka ${ }^{3}$

\section{Introduction}

The International Journal of Religion (IJOR) was founded to fill a gap: to discover more about how religion impacts on society and politics both within and between countries. IJOR will examine how and why religion influences national and international politics, society, and economics. IJOR will be comprehensive, inter-disciplinary and researched-based. IJOR will do all it can to be a respected social scientific journal of high academic quality. IJOR invites scholars, researchers, thinkers and practitioners working on and interested in these issues to contribute, in what the journal intends to be a conducive environment to stimulate critical and independent thinking.

IJOR's raison d'etre is the long running and continuing debate about how secularisation influences the public roles of religion. The debate has lasted half a century or more. It was stimulated in the $1960 \mathrm{~s}$ by the prediction of the sociologist, Peter Berger, that both industrialised and hence modernised, as well as industrialising and hence modernising, countries would inevitably become secular over time, implying that religion's influence would decline significantly. Today, while it is widely agreed that the public role of religion is variable in countries around the world, overall it has not lost influence to the extent that Berger and other believed it would. Instead, its influence has evolved in ways that often significantly affects our lives (Fox 2019). As evidence, we can mention some important events, including: Iran's Islamic Revolution (1979), the USA's Carter Doctrine which influenced international religious freedom, the emergence of religious political parties around the world, including in the 'secular' West and, tragically, the 9/11 attacks (on 11 September 2001) which killed 3,000 people directly. These events underline that religion has not gone away - instead, its influence is often very great on politics and society around the world (Haynes 2011; Thomas 2005; Sandal and Fox 2013).

Debates about religion's public role include (1) how central is religion to political outcomes, both domestically and in international relations, especially in relation to conflict? (Philpott 2007; Norris and Inglehart 2011; Haynes 2008; Fox 2018; Bettiza 2019). (2) How do we theoretically explain religion's involvement in politics and society? (Sandal and James 2011) (3) How does religion affect our understanding of economics? (Gill 2019) (4) What is the social impact of religion in public spaces, for example, in the controversial issue in many Western countries of Muslim women wearing face

\footnotetext{
${ }^{1}$ Jeffrey Haynes, PhD, Emeritus Professor, School of Social Sciences, London Metropolitan University, Department of Political Science and International Relations, London, UK. E-mail: tsjhayn1@londonmet.ac.uk

${ }^{2}$ Ahmet Erdi Ozturk, PhD, Lecturer, Department of Political Science and International Relations, London Metropolitan University, London, UK. E-mail: e.ozturk@londonmet.ac.uk

${ }^{3}$ Eric M. Trinka, PhD, Lecturer, James Madison University, United States. E-mail: trinkaem@jmu.edu
} 


\section{Editorial: Launching the International Journal of Religion}

coverings? (Casanova 2011) (5) How does shared religious belief affect diasporic groups around the world? (Vertovec 2004) (6) What is the relationship between religion and our understanding of gender in both 'modern' and 'modernising' countries? (Nynas 2016), and (7) How do certain religious traditions, such as Islam, affect a country's economic, political and social development? (Kuru 2019). Aside from these specific questions, scholars and researchers interested in the public role of religion also ask how and to what extent conflicts, including those associated with terrorism, migration and inter-ethnic disputes, are linked to religion (Haynes 2005; Cesari 2019; Henne 2016; Trinka 2019; Gürses and Öztürk 2020). Stimulated by recent developments in Europe, the USA, India, Brazil and elsewhere, scholars and researchers now examine how and why religion impacts on populism and nationalism (Ozturk 2019; Koesel 2014). Finally in addition to these longstanding issues, another has emerged in recent years: how does religion affect the 'clash of civilizations', a paradigm advanced originally by the political scientist, Samuel Huntington (1996; see Haynes 2019 for an up to date analysis of the 'clash of civilizations').

These issues have received much attention in both popular and scholarly fora. In addition, think tanks and research centres around the world investigate the impact of religion on politics and society. Book series and dedicated academic journals also cover them in depth. With all this attention and coverage why do we need another journal? While there are already several important academic journals examining religion and related issues in social scientific contexts, none focuses on the multiple issues that IJOR does. But no journal can develop without its contributors: Please join us. We invite you to enter the world of the journal, and contribute to its debates, discussions and research findings.

\section{References}

Bettiza, G. (2019). Finding Faith in Foreign Policy: Religion and American Diplomacy in a Postsecular World. Oxford: Oxford University Press.

Casanova, J. (2011). Public religions in the modern world. Chicago: University of Chicago Press.

Cesari, J. (2019). Civilization as Disciplinization and the Consequences for Religion and World Politics. The Review of Faith \& International Affairs 17(1): 24-33.

Fox, J. (2019). A world survey of secular-religious competition: state religious policy from 1990 to 2014. Religion, State \& Society 47(1): 10-29.

Fox, J. (2018). An introduction to religion and politics: Theory and practice. London: Routledge.

Gill, A. (2019). A Great Academic Re-awakening: The Return to a Political Economy of Religion. In: J. Carvalho, S. Iyer, J, Rubin(eds.) Advances in the Economics of Religion, pp. 361-376. Cham: Palgrave Macmillan.

Gurses, M. and A. E. Ozturk (2020). Religion and Armed Conflict: Evidence from the Kurdish Conflict in Turkey. Journal for the Scientific Study of Religion, 59(2): 327-340.

Haynes, J. (2011). Religion, politics and international relations: Selected essays. London: Taylor \& Francis.

Haynes, J. (2019). From Huntington to Trump: Thirty Years of the Clash of Civilizations. New York: Lexington Books.

Haynes, J. (ed.) (2008). Routledge handbook of religion and politics. London: Routledge.

Haynes, J. (2005). Religion and international relations after '9/11'. Democratization, 12(3): 398-413.

Henne, P. (2016). Islamic politics, Muslim states, and counterterrorism tensions. Cambridge: Cambridge University Press.

Koesel, K. J. (2014). Religion and authoritarianism: Cooperation, conflict, and the consequences. Cambridge: Cambridge University Press.

Kuru, A.T. (2019). Islam, authoritarianism, and underdevelopment: A global and historical comparison. Cambridge: Cambridge University Press.

Norris, P., and R. Inglehart. (2011). Sacred and secular: Religion and politics worldwide. Cambridge: Cambridge University Press.

Nynäs, P. (2016). Religion, gender and sexuality in everyday life. London: Routledge.

Öztürk, A. E. (2019). An alternative reading of religion and authoritarianism: the new logic between religion and state in the AKP's New Turkey. Southeast European and Black Sea Studies 19(1): 79-98. 
Philpott, D. (2007). Explaining the political ambivalence of religion. American Political Science Review, 505-525.

Sandal, N. A., and P. James (2011). Religion and International Relations theory: Towards a mutual understanding. European Journal of International Relations, 17(1): 3-25.

Sandal, N., and J. Fox (2013). Religion in international relations theory: interactions and possibilities. London: Routledge.

Thomas, S. (2005). The global resurgence of religion and the transformation of international relations: The struggle for the soul of the twenty-first century. Springer.

Trinka, E. M. (2019). The End of Islands: Drawing Insight from John's Apocalypse to Respond to Prisoner Radicalization and Apocalyptically-Oriented Terrorism. Religions 10(2): 1-14. DOI:10.3390/rel10020073

Vertovec, S. (2004). Religion and diaspora. New approaches to the study of religion 2, 275-304. 